\title{
OXT wt Allele
}

National Cancer Institute

\section{Source}

National Cancer Institute. OXT wt Allele. NCI Thesaurus. Code C52423.

Human OXT wild-type allele is located in the vicinity of 20p13 and is approximately $1 \mathrm{~kb}$ in length. This allele, which encodes oxytocin-neurophysin 1 protein, is involved in the regulation of smooth muscle contraction during both childbirth and lactation, cardiovascular homeostasis and complex neural processes such as cognition, adaptation and maternal behavior. 